\title{
Zero-Gap Alkaline Water Electrolysis Using lon-Solvating Polymer Electrolyte Membranes at Reduced KOH Concentrations
}

Kraglund, Mikkel Rykær; Aili, David; Jankova Atanasova, Katja ; Christensen, Erik; Li, Qingfeng; Jensen, Jens Oluf

Published in:

Journal of The Electrochemical Society

Link to article, DOI:

$10.1149 / 2.0161611$ jes

Publication date:

2016

Document Version

Publisher's PDF, also known as Version of record

Link back to DTU Orbit

Citation (APA):

Kraglund, M. R., Aili, D., Jankova Atanasova, K., Christensen, E., Li, Q., \& Jensen, J. O. (2016). Zero-Gap Alkaline Water Electrolysis Using lon-Solvating Polymer Electrolyte Membranes at Reduced KOH

Concentrations. Journal of The Electrochemical Society, 163(11), F3125-F3131.

https://doi.org/10.1149/2.0161611jes

\section{General rights}

Copyright and moral rights for the publications made accessible in the public portal are retained by the authors and/or other copyright owners and it is a condition of accessing publications that users recognise and abide by the legal requirements associated with these rights.

- Users may download and print one copy of any publication from the public portal for the purpose of private study or research.

- You may not further distribute the material or use it for any profit-making activity or commercial gain

- You may freely distribute the URL identifying the publication in the public portal 


\title{
Zero-Gap Alkaline Water Electrolysis Using Ion-Solvating Polymer Electrolyte Membranes at Reduced KOH Concentrations
}

\author{
Mikkel Rykær Kraglund, = David Aili, ${ }^{=, z}$ Katja Jankova, Erik Christensen, Qingfeng Li, ${ }^{*}$ \\ and Jens Oluf Jensen
}

Department of Energy Conversion and Storage, Technical University of Denmark, DK-2800 Kgs. Lyngby, Denmark

\begin{abstract}
Membranes based on poly(2,2'-( $m$-phenylene)-5,5-bibenzimidazole) ( $m$-PBI) can dissolve large amounts of aqueous KOH to give electrolyte systems with ion conductivity in a practically useful range. The conductivity of the membrane strongly depends on the concentration of the aqueous $\mathrm{KOH}$ phase, reaching about $10^{-1} \mathrm{~S} \mathrm{~cm}^{-1}$ or higher in $15-25 \mathrm{wt} \% \mathrm{KOH}$. Herein, $m$-PBI membranes are systematically characterized with respect to performance and short-term stability as electrolyte in a zero-gap alkaline water electrolyzer at different $\mathrm{KOH}$ concentrations. Using plain uncatalyzed nickel foam electrodes, the cell based on $m$-PBI outperforms the cell based on the commercially available state-of-the-art diaphragm and reaches a current density of $1500 \mathrm{~mA} \mathrm{~cm}^{-2}$ at $2.4 \mathrm{~V}$ in $20 \mathrm{wt} \% \mathrm{KOH}$ at $80^{\circ} \mathrm{C}$. The cell performance remained stable during two days of operation, though post analysis of the membrane using size exclusion chromatography and spectroscopy reveal evidence of oxidative degradation of the base polymer at $\mathrm{KOH}$ concentrations of $15 \mathrm{wt} \%$ and higher.

(C) The Author(s) 2016. Published by ECS. This is an open access article distributed under the terms of the Creative Commons Attribution 4.0 License (CC BY, http://creativecommons.org/licenses/by/4.0/), which permits unrestricted reuse of the work in any medium, provided the original work is properly cited. [DOI: 10.1149/2.0161611jes] All rights reserved.
\end{abstract}

Manuscript submitted May 16, 2016; revised manuscript received July 1, 2016. Published July 21, 2016. This paper is part of the JES Focus Issue on Electrolysis for Increased Renewable Energy Penetration.

Converting surplus electrical energy into hydrogen by water electrolysis represents an attractive approach to balance the electric grid when an increasing fraction of the power input originates from fluctuating renewable sources. ${ }^{1}$ Characterized by their robustness and durability, alkaline electrolyzers have been available for a long time on a commercial basis for large scale hydrogen and oxygen production through electrochemical water splitting. ${ }^{2,3}$ The alkaline environment allows for a cell construction completely free from noble metals, where the oxygen ${ }^{4-6}$ and hydrogen ${ }^{7-9}$ evolution reactions readily occur on nickel and other transition metal-based materials. The electrodes are separated by an aqueous solution of potassium hydroxide confined in a porous diaphragm to reduce the intermixing of the product gasses. Between the diaphragm and the electrode is an electrolyte-filled gap to facilitate gas removal. This cell design gives an interelectrode distance in the range of a few millimeters and therefore a relatively large internal resistance, ${ }^{3,10}$ even though the specific conductivity of the aqueous potassium hydroxide electrolyte used is remarkably high. ${ }^{11-13}$ Significant performance improvements of the conventional technology have been demonstrated using e.g. increased temperatures, ${ }^{14}$ novel diaphragm materials,,${ }^{15-19}$ active bubble removal $^{20,21}$ or advanced electrode designs. ${ }^{22}$

Replacing the diaphragm with an ion-conducting membrane represents a new direction in the development of advanced alkaline electrolyzers as recently discussed by Pletcher and $\mathrm{Li}^{23}$ It allows for a zero-gap design with an inter-electrode distance of less than $100 \mu \mathrm{m}$, in which the membrane is sandwiched in between two porous electrodes. One approach in this connection is to use alkaline ion exchange membranes (AEM) based on quaternary ammoniumfunctionalized polymers, ${ }^{24-26}$ but improving the stability of the polymer backbone ${ }^{27}$ as well as of the anion exchange moieties ${ }^{28}$ are apparent challenges.

An alternative approach is to use a membrane based on an aqueous electrolyte dissolved in a polymer matrix. The ion-solvating polymer electrolytes are often soluble in water ${ }^{29}$ but as first demonstrated by Xing and Savadogo, ${ }^{30}$ poly $\left(2,2^{\prime}\right.$-( $m$-phenylene $)-5,5$-bibenzimidazole $)$ ( $m$-PBI) equilibrated in aqueous potassium hydroxide forms a mechanically robust ion-solvating polymer electrolyte system with high ion conductivity. The composition of such ternary polymer electrolyte membranes strongly depends on the $\mathrm{KOH}$ concentration of the

\footnotetext{
$=$ These authors contributed equally to this work.

* Electrochemical Society Member.

zE-mail: larda@dtu.dk
}

surrounding solution. The potassium poly(benzimidazolide) ionomer form of $m$-PBI (Figure 1, right) has been found to predominate at concentrations higher than about $15 \mathrm{wt} \%\left(3 \mathrm{~mol} \mathrm{~L}^{-1}\right) .{ }^{31}$ As a result, the intermolecular hydrogen bonding responsible for the mechanical toughness of the pristine material is lost, which allows for extensive volume swelling and electrolyte uptake and a therefore a dramatic conductivity increase. ${ }^{31,32}$

The practical use of this electrolyte type has been demonstrated repeatedly in hydrogen ${ }^{30,33,34}$ and direct alcohol ${ }^{35-39}$ fuel cells, supercapacitors ${ }^{40}$ or as an anion conducting phase in alkaline fuel cell catalyst layers. ${ }^{41-43}$ Recently, potassium hydroxide equilibrated membranes based on $m$ - $\mathrm{PBI}^{44,45}$ and derivatives thereof $\mathrm{f}^{46}$ have been demonstrated to outperform conventional porous diaphragms in alkaline water electrolysis tests. Chemically, the $m$-PBI shows excellent stability in aqueous $\mathrm{KOH}$ in the lower concentration range and seems virtually unaffected after treatment in $5-10 \mathrm{wt} \% \mathrm{KOH}$ at $88^{\circ} \mathrm{C}$ for more than 6 months. ${ }^{47}$

The present work systematically investigates the influence of electrolyte concentration on the performance of a zero-gap alkaline water electrolyzer using porous nickel foam electrodes and ternary $m$-PBI based membranes as electrolyte. Furthermore, short-term stability tests were carried out to assess the effects of cell operation in the light of the membrane stability.

\section{Experimental}

Materials.-The $m$-PBI membranes were prepared as reported elsewhere, ${ }^{31}$ using $m$-PBI from Danish Power Systems ApS with an inherent viscosity $\eta_{i n h}$ of $0.95 \mathrm{dL} \mathrm{g}^{-1}$ as determined in $96 \mathrm{wt} \% \mathrm{H}_{2} \mathrm{SO}_{4}$ (500 $\mathrm{mg} \mathrm{dL}^{-1}$ solid content) at $30.0^{\circ} \mathrm{C}$ using an Ubbelohde capillary viscosimeter. Based on the previously reported swelling data, ${ }^{31}$ the membranes were cast to different thicknesses so that membranes with a thickness of 50-60 $\mu \mathrm{m}$ were obtained after equilibration in aqueous $\mathrm{KOH}$ regardless of the $\mathrm{KOH}$ concentration. The aqueous $\mathrm{KOH}$ solutions were prepared by dissolving $\mathrm{KOH}$ pellets (Sigma-Aldrich, assay $\geq 85 \% \mathrm{KOH}, \leq 1 \% \mathrm{~K}_{2} \mathrm{CO}_{3}$ ) in demineralized water and the concentrations were confirmed by density measurements and compared with literature data. ${ }^{48}$ Aqueous $\mathrm{KCl}$ conductance standard solutions (Sigma-Aldrich, 1.0 and $0.1 \mathrm{~mol} \mathrm{~L}^{-1}$ ) were used for the calibration of the conductivity cell. The nickel foam (thickness $1100 \mu \mathrm{m}$ ) was purchased from American Elements. Zirfon Pearl 500 UTP was supplied by Agfa. 


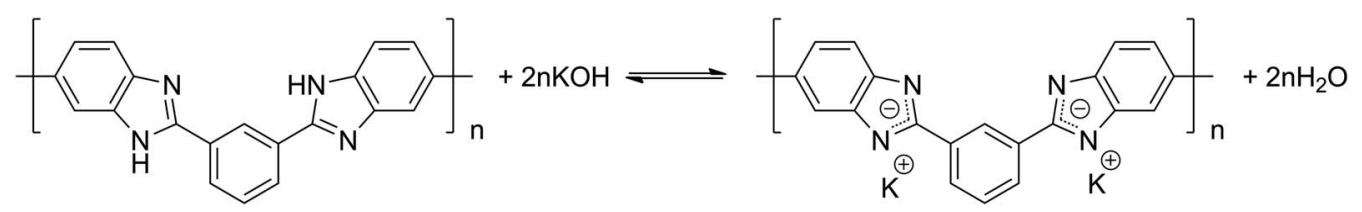

Figure 1. The chemical structure of $m$-PBI in the neutral pristine form (left) and in the potassium poly(benzimidazolide) form (right).

Membrane characterization.-The ion conductivity was measured in a tubular cell (inner diameter $0.9 \mathrm{~cm}$ ) composed of two separate blocks made of poly(tetrafluoroethylene) (PTFE). One electrode made of nickel mesh was fixed in each block using PTFE gaskets. The cell was assembled using screws made of poly(ether ether ketone) (PEEK) and the interelectrode distance in the cell assembly was 4.6 $\mathrm{mm}$. The cell was placed with the tubular void in a vertical orientation in a PTFE beaker filled with aqueous $\mathrm{KOH}$, and placed in an oven for temperature control. The resistance between the electrodes, taken as $Z_{r e}$ at $Z_{i m}=0 \Omega$, was recorded by electrochemical impedance spectroscopy using a VersaStat 3 from Princeton Applied Research. The ion conductivity $\sigma$ of the $m$-PBI membranes was calculated according to Equation 1, where $t$ is the thickness taken as an average of 5 measurements, $R$ is the measured resistance taken as an average of 4 scans, $R_{\text {blank }}$ is the resistance recorded for the electrolyte without the membrane, and $A$ is the cross-sectional area of the cell. The thickness at 40,60 and $80^{\circ} \mathrm{C}$ was taken as the initial membrane thickness before increasing the temperature.

$$
\sigma=t /\left(\left(R-R_{\text {blank }}\right) \times A\right)
$$

Scanning electron microscopy (SEM) was carried out on a Carl Zeiss EVO MA10. The cross-sections were prepared by ion-milling using a Hitachi E-3500. The Fourier transform infrared (FTIR) spectra were recorded on a Perkin Elmer Spectrum Two in attenuated total reflectance (ATR) mode. The ${ }^{1} \mathrm{H}$ nuclear magnetic resonance $\left({ }^{1} \mathrm{H}\right.$ NMR) spectra were recorded on a Bruker Ascend operating at 400 MHz. Deuterated dimethyl sulfoxide (DMSO- $d_{6}$ ) was used as solvent and the solvent residual signal at $2.50 \mathrm{ppm}$ was used as reference. Size exclusion chromatography (SEC) was carried out on a Shimadzu HPLC Instrument, equipped with 2 PolarSil columns (100 and $300 \AA$ ) from Polymer Standards Service (PSS) and a Shimadzu refractive index detector. The system was controlled via the LabSolutions GPC software, which was also used for the data processing and calculations. The mobile phase was composed of DMAc containing $2.5 \mathrm{wt} \%$
$\mathrm{LiCl}$. The temperature of the columns was kept at $60^{\circ} \mathrm{C}$ and the flow rate was $1 \mathrm{~mL} \mathrm{~min}^{-1}$. The peak average molecular weight $M_{p}$, number average molecular weight $M_{n}$, weight average molecular weight $M_{w}$ and the polydispersity index PDI $\left(M_{w} / M_{n}\right)$ were calculated based on a calibration using narrow molecular weight poly(methyl methacrylate) (PMMA) standards from PSS in the molecular weight range of 800-1600000 $\mathrm{g} \mathrm{mol}^{-1}$. For the ${ }^{1} \mathrm{H}$ NMR and SEC measurements the polymer was dissolved at $120^{\circ} \mathrm{C}$ and the solutions were filtered through $0.45 \mu \mathrm{m}$ PTFE syringe filters.

Water electrolysis testing.-The water electrolysis experiments were performed in a zero-gap laboratory cell mounted in the setup schematically represented in Figure 2a. Gear pumps circulated the electrolyte in separated compartments at flow rates of $100-120 \mathrm{~mL}$ $\mathrm{min}^{-1}$. The electrolysis cell is visualized in Figure $2 \mathrm{~b}$, consisting of flow field plates with a linear pattern made from stainless steel coated with electroless nickel containing phosphorous (1), nickel foam electrodes with a diameter of $38.5 \mathrm{~mm}$ (area $\left.11.6 \mathrm{~cm}^{2}\right)(2), m$-PBI membrane or Zirfon diaphragm (diameter $44.5 \mathrm{~mm}$ ) (3), and PTFE gaskets with an outer diameter of $70 \mathrm{~mm}$ and an inner diameter of 39 or $45 \mathrm{~mm}$ (4). Heating elements and a thermocouple were placed within the flow field plates to control the temperature. An Elektro Automatik EA-PS 3016-20 B unit controlled by a LabVIEW interface was used for the power supply. The cells were carefully assembled in a horizontal orientation. The cells were conditioned at $10-50 \mathrm{~mA} \mathrm{~cm}^{-2}$ for 15-60 minutes before the first polarization curve was recorded, and thereafter operated in galvanostatic mode at $200 \mathrm{~mA} \mathrm{~cm}^{-2}$ or potentiostatic mode at $1.7 \mathrm{~V}$ or $2.0 \mathrm{~V}$. Polarization curves were recorded after $0,2,25$ and 48 hours of operation by scanning the potential from $1.225 \mathrm{~V}$ to 2.2 or $2.5 \mathrm{~V}$ with a scan rate of $2.5 \mathrm{mV} \mathrm{s}^{-1}$. Since there were no autonomous water feed, or any balancing of concentration gradients and electrolyte level, water and electrolyte were added manually, usually after approximately 1 day. a)

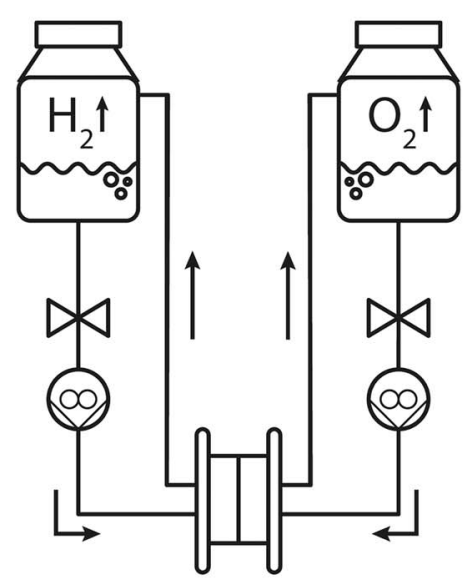

b)

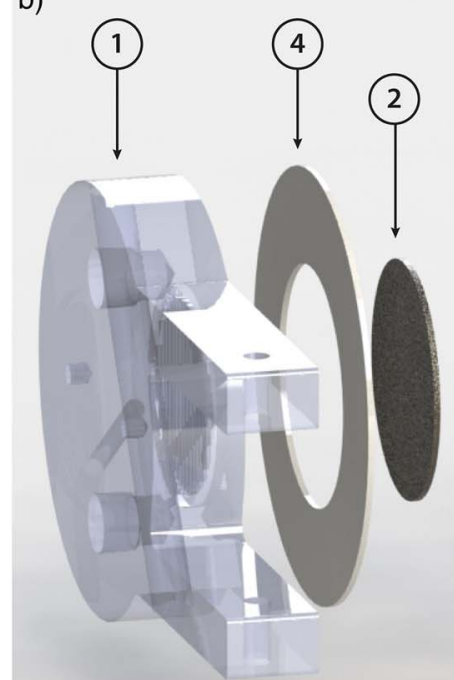

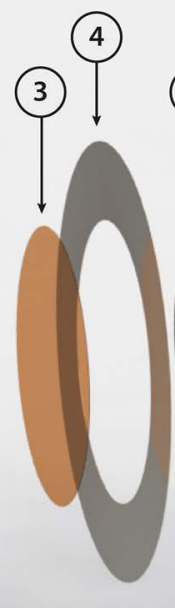

(2)

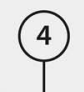

1
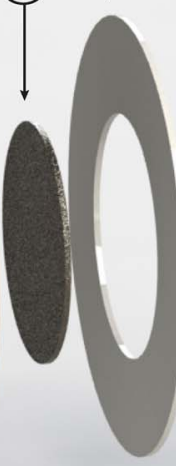
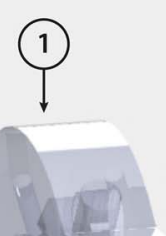

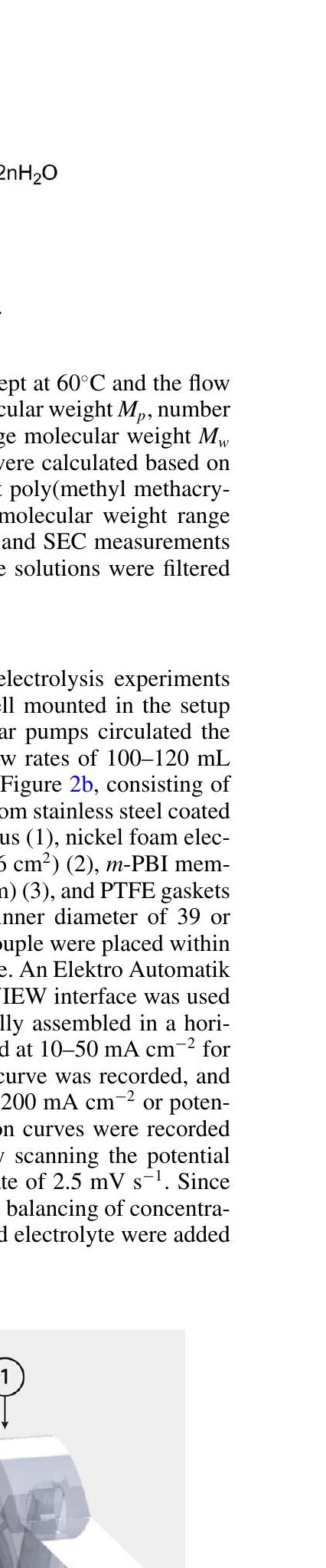




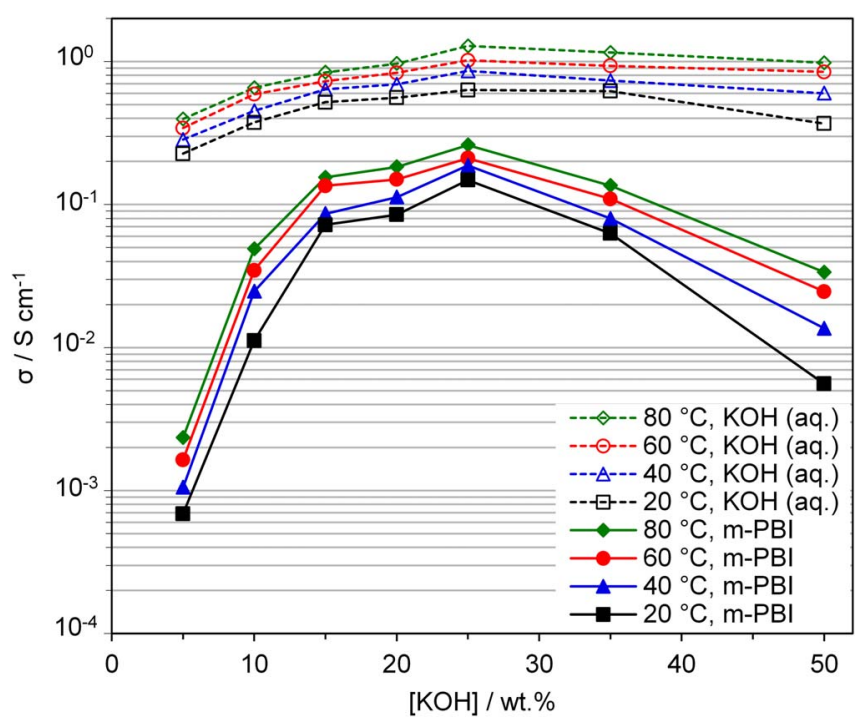

Figure 3. Ion conductivity isotherms of aqueous $\mathrm{KOH}$ (open symbols) and of $m$-PBI equilibrated in the corresponding $\mathrm{KOH}$ solutions (solid symbols).

\section{Results and Discussion}

The ion conductivity of the $m$-PBI membranes was measured after equilibration in aqueous $\mathrm{KOH}$ of different concentrations, as shown in Figure 3. The conductivity of the corresponding aqueous $\mathrm{KOH}$ solutions are shown for comparison and were in agreement with data in the literature. ${ }^{13}$ When the $\mathrm{KOH}$ concentration of the bulk solution was increased from 5 to $15 \mathrm{wt} \%$, the ion conductivity of the $m$-PBI membrane was increased by two orders of magnitude from 0.7 to 72 $\mathrm{mS} \mathrm{cm}{ }^{-1}$. By further increasing the concentration of the bulk solution to 20 and $25 \mathrm{wt} \%$, the conductivity of the $m$-PBI membrane was further increased to 85 and $148 \mathrm{mS} \mathrm{cm}^{-1}$, respectively.

The working temperature of an alkaline electrolyzer is, however, normally around $80^{\circ} \mathrm{C}$ and it is therefore of interest to measure the conductivity as a function of temperature. The conductivity of the bulk solution as well as that of the $m$-PBI membrane increased with increasing temperature. The conductivity of the $m$-PBI membrane was found to peak in $25 \mathrm{wt} \%$ at $80^{\circ} \mathrm{C}$, reaching $260 \mathrm{mS} \mathrm{cm}^{-1}$, but even in $15 \mathrm{wt} \%$ aqueous $\mathrm{KOH}$ the conductivity was as high as $155 \mathrm{mS}$ $\mathrm{cm}^{-1}$. It indicates that the $\mathrm{KOH}$ concentration can be significantly reduced from typically $30 \mathrm{wt} \%$ for conventional electrolyzers, resulting in a significant relief on the system and auxiliary units as recently discussed by Diaz et al. ${ }^{46}$ It should be remarked that the relative uncertainty of the conductivity data increases as the difference between $R$ and $R_{\text {blank }}$ is getting smaller, i.e. in the region where the conductivity peaks. Furthermore, the membranes tend to be mechanically soft in this $\mathrm{KOH}$ concentration range, ${ }^{31}$ and the precision of the thickness determination is therefore reduced.

Based on the four data points, the activation energy for ion conductivity $E_{a}$ was estimated by fitting the data to the Arrhenius equation (Eq. 2 in logarithmic form), where $\sigma$ is the ion conductivity, $\sigma_{0}$ is the pre-exponential factor, $T$ is the absolute temperature and $R$ is the universal gas constant.

$$
\ln (\sigma)=\ln \left(\sigma_{0}\right)-\left(E_{a} / R T\right)
$$

For aqueous the $\mathrm{KOH}$ solutions, the activation energy was found to be in the range of $8-15 \mathrm{~kJ} \mathrm{~mol}^{-1}$ and tended to increase slightly with increasing $\mathrm{KOH}$ concentration, in good agreement with the data predicted by the model developed by Gilliam et al. ${ }^{13}$ Ion conductivity in aqueous basic solutions ${ }^{49,50}$ and polymeric materials ${ }^{51}$ represent fundamentally complex processes involving many interacting species. The observed activation energies fall in the range for the typical structure diffusion (Grotthuss) mechanism. Interestingly, the activation energy for ion conductivity of the $m$-PBI membrane equi-

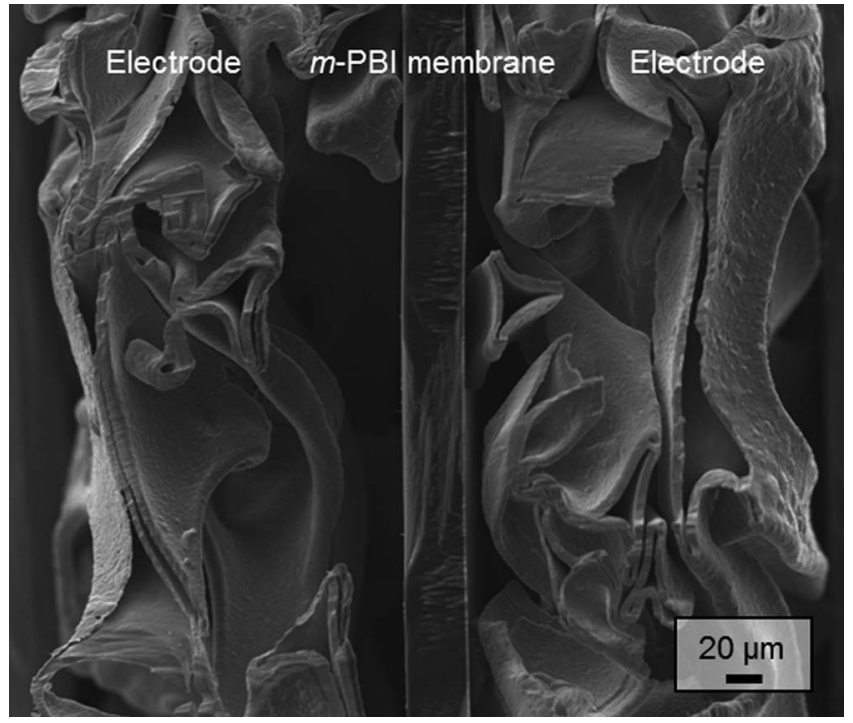

Figure 4. Cross-sectional SEM micrograph of the membrane electrode assembly based on a dry undoped membrane.

librated in aqueous $\mathrm{KOH}$ was only marginally higher than that of the bulk solutions in the intermediate concentration range (15-35 wt\%), i.e. in the range where the ionic form of $m$-PBI predominates in the non-crystalline form and where remarkably high electrolyte uptake occurs ${ }^{31}$ indicating a quasi-liquid like conduction.

For the alkaline water electrolysis tests, the $m$-PBI membranes were sandwiched in between two electrodes made of nickel foam to form a membrane electrode assembly (MEA). The concept is illustrated in Figure 4, showing a cross-sectional SEM micrograph of a MEA using a dry pristine $m$-PBI membrane. For the cell tests the $m$ $\mathrm{PBI}$ membranes were pre-equilibrated in aqueous $\mathrm{KOH}$ to give MEAs with inter-electrode distances in the range of 50-60 $\mu \mathrm{m}$.

The MEAs were tested in the alkaline electrolyzer at $80^{\circ} \mathrm{C}$ and under ambient pressure. As shown in Figure 5, the cell operating with $5 \mathrm{wt} \%$ aqueous $\mathrm{KOH}$ as electrolyte reached only a modest current density of $22 \mathrm{~mA} \mathrm{~cm}^{-2}$ at $2.4 \mathrm{~V}$, apparently due to the low ion conductivity of $m$-PBI in this environment (Figure 3 ). As expected from the conductivity data, the current density at $2.4 \mathrm{~V}$ was significantly

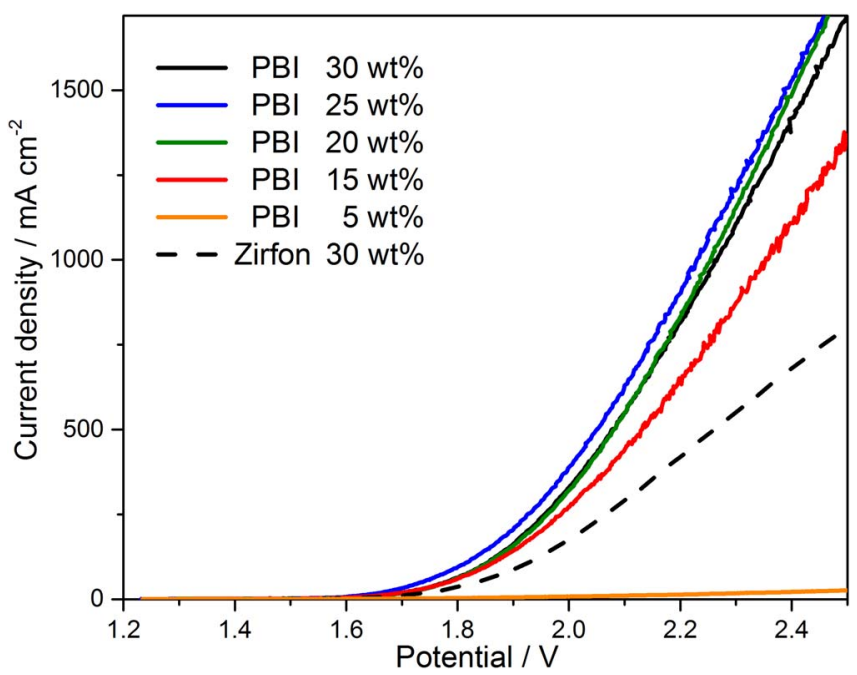

Figure 5. Electrolyzer polarization at $80^{\circ} \mathrm{C}$ using $m$-PBI membranes (solid lines) as electrolyte at concentrations ranging from 5-30 wt \% . The polarization curve for a cell based on a commercially available Zirfon diaphragm is shown for comparison (dashed line). 

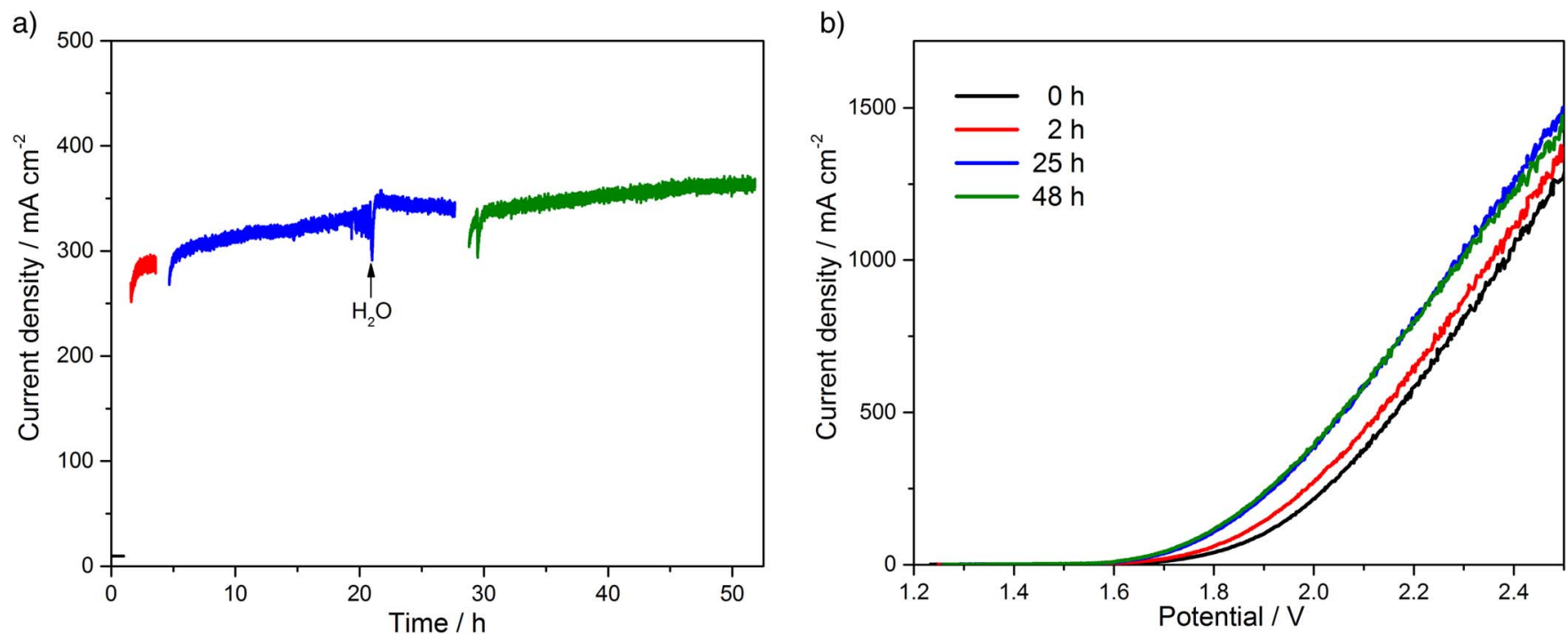

Figure 6. Chronoamperometric curves at $2.0 \mathrm{~V}$ (a) and polarization curves after $0,2,25$ and 48 hours at $2.0 \mathrm{~V}$ (b) for the cell based on $m$-PBI cell operating with $15 \mathrm{wt} \%$ aqueous $\mathrm{KOH}$ at $80^{\circ} \mathrm{C}$.

increased by increasing the $\mathrm{KOH}$ concentration to $15 \mathrm{wt} \%$, reaching $1100 \mathrm{~mA} \mathrm{~cm}^{-2}$. The lowest apparent ohmic resistance was observed for the cell operating with $20 \mathrm{wt} \%$ aqueous $\mathrm{KOH}$, where almost 1500 $\mathrm{mA} \mathrm{cm} \mathrm{c}^{-2}$ was reached at $2.4 \mathrm{~V}$. For comparison, the cell equipped with the commercially available state-of-the-art diaphragm did not even reach $700 \mathrm{~mA} \mathrm{~cm} \mathrm{~cm}^{-2}$ at $2.4 \mathrm{~V}$ even though the typical $30 \mathrm{wt} \%$ $\mathrm{KOH}$ concentration was used. Interesting to note is the improved polarization in the activation region at low current densities for the cell operating with $25 \mathrm{wt} \%$ aqueous $\mathrm{KOH}$. This can be explained by a more significant degree of anode activation from iron contaminants at the time of the given measurements. Iron is present as impurities in the electrolyte, but is also bleeding from external system components exposing steel to the heated electrolyte such as pumps and valves. It is well known that iron impurities significantly improve the oxygen evolution activity of nickel, ${ }^{52,53}$ but other factors such as membrane uniformity, precision of electrode alignment, and contamination are expected to affect the appearance of the polarization curves as well.

Many factors contribute to the total internal resistance of an alkaline electrolyzer, including contact resistances, bubble formation and especially ohmic resistance in the electrolyte. As a rough estimation of the internal resistance of the system, the polarization data at current densities higher than $5 \mathrm{~mA} \mathrm{~cm}{ }^{-2}$ were fitted by non-linear regression to Equation 3, where $a$ is a constant, $b$ is the Tafel slope, $i$ is the current density and $R_{A S R}$ is the area specific resistance.

$$
E=a+b \log (i)+i R_{A S R}
$$

While the calculated Tafel slope contains contributions from electrode processes on both electrodes, the area specific resistance for the $m$-PBI based cells operating with $5,15,20,25$ and $30 \mathrm{wt} \%$ is assumed to originate primarily from the membrane. The obtained number corresponds to in-situ specific conductivities of $0.4,15,25,22$ and $19 \mathrm{mS} \mathrm{cm}{ }^{-1}$, respectively. Similarly, the area specific resistance for the cell based on the Zirfon diaphragm corresponds to an in-situ ion conductivity of $82 \mathrm{mS} \mathrm{cm}^{-1}$ with $30 \mathrm{wt} \%$ aqueous $\mathrm{KOH}$. As previously observed, ${ }^{19,44}$ the in-situ conductivity was considerably lower than the conductivity recorded ex-situ, likely due to concentration polarization, intra-electrode ion transport in the $\mathrm{KOH}$ solutions, and the increasing bubble formation blocking the ion conducting pathways and surface sites at higher current densities. ${ }^{2}$ While the best performance observed, i.e. $m$-PBI in $20 \mathrm{wt} \%$, does not match expectations based on the herein presented conductivity data, it does fit previous measurements. ${ }^{31}$

An improved performance at lower concentrations is not unexpected, even when conductivity data alone suggest a different trend.
The viscosity decreases at lower concentrations, ${ }^{48}$ which promotes bubble dislocation and therefore reduces the gas bubble surface coverage and facilitates gas escape through the pores in the structure of the nickel foam electrode. Depending on electrode geometry and pore size distribution, the effects of changes in viscosity may be quite significant.

Chemically, $m$-PBI shows good stability in aqueous $\mathrm{KOH}$ in the lower concentration range $(<10 \mathrm{wt} \%)$ for 6 months at temperatures above $80^{\circ} \mathrm{C},{ }^{47}$ but it gradually degrades by hydrolysis at higher concentrations. However, it can be expected that the membrane degradation rate is enhanced due to the electrode polarization and the formation of highly reactive species and reaction intermediates (e.g. radicals) at the membrane surfaces. For example, oxidation of the polymer may occur near the anode where oxygen is evolved. When doped with phosphoric acid, $m$-PBI appears stable for thousands of hours in fuel cells ${ }^{54}$ but severely degrades within a few hours when operated in steam electrolysis mode..$^{5}$

To assess the effect of polarization on a slightly longer time-scale, the cells operating with 5,15 and $30 \mathrm{wt} \% \mathrm{KOH}$ were kept at 1.7 or $2.0 \mathrm{~V}$ for 2 days and the current density was recorded as functions of time. The current density development for the cell operated in $15 \mathrm{wt} \%$ at $2.0 \mathrm{~V}$ is shown in Figure 6a. Polarization curves were recorded after certain durations of set-point operation as shown in Figure 6b. Due to electrode activation, perhaps from iron impurities as discussed above, ${ }^{53}$ the onset potential was observed to improve as experiments ran for longer periods of time and more polarization sweeps were recorded. Currently, Fe-doped nickel hydroxides are even considered the most active alkaline oxygen evolution catalyst. ${ }^{6}$ Conversely, no apparent changes of the slope in the linear region of the polarization curve were evident, indicating no significant changes in ohmic resistance.

The cells were run potentiostatically for a total of 48 hours and several polarization curves reaching higher potentials for short durations were recorded. From the polarization data, no changes in cell performance could be ascribed to the membrane degradation and membrane integrity appeared good after disassembly for all cells except the cell operated in $30 \mathrm{wt} \%$ at $2.0 \mathrm{~V}$. In the latter case, after the cell was disassembled a hole was observed in the membrane close to the electrolyte inlet, likely due to mechanical stress caused by liquid pressure fluctuations. A migration of the electrolyte from anode to cathode compartment was observed during operation, and the phenomenon seemed to increase with increasing current density. It was also observed that the membrane equilibrated in $30 \mathrm{wt} \% \mathrm{KOH}$ was prone to short circuiting even during cell assembly, likely due to its 

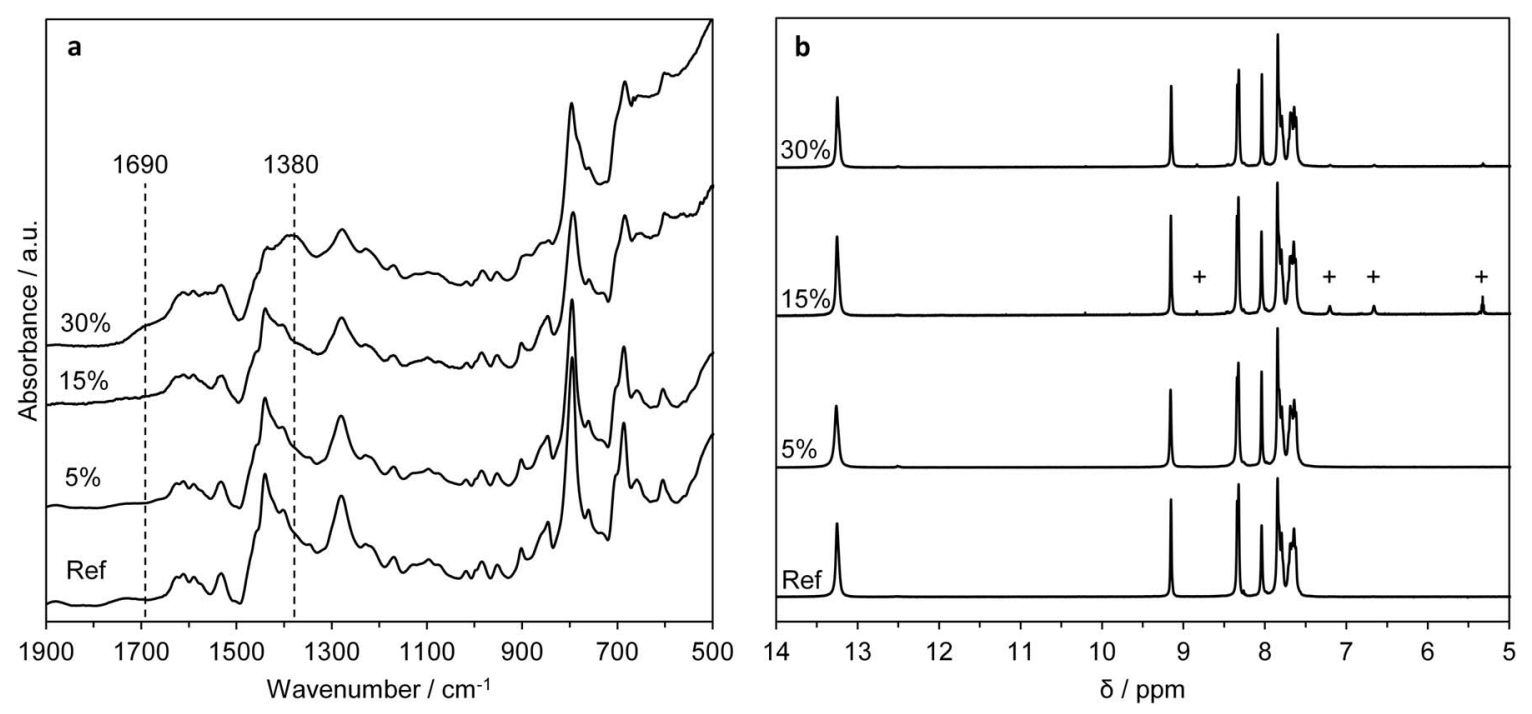

Figure 7. FTIR (a) and ${ }^{1} \mathrm{H}$ NMR (b) spectra of the $m$-PBI membranes after water electrolysis operation for $48 \mathrm{~h}$ at $2.0 \mathrm{~V}$ in 5,15 and $30 \mathrm{wt} \%$ aqueous KOH.

low mechanical strength..$^{31,47}$ To reduce the surface roughness of the electrodes they were therefore pressed with spacers before cell assembly to a thickness of $210 \mu \mathrm{m}$ for the measurements with $m$-PBI and $420 \mu \mathrm{m}$ for the measurements with Zirfon. It is worth noting that a gradually degrading membrane would not necessarily affect the electrochemical performance of the cell negatively, but could result in mechanical deterioration of the membrane ultimately leading to shortcircuiting. Unlike cells based on ion exchange membranes, where the only conducting medium is the membrane, the liquid electrolyte could substitute the membrane locally in this system. An increased gas crossover is then expected, but it was not possible to monitor developed gasses with the experimental setup used.

The FTIR and ${ }^{1} \mathrm{H}$ NMR spectra of the $m$-PBI membranes after operation at $2.0 \mathrm{~V}$ for $48 \mathrm{~h}$ in 5,15 and $30 \mathrm{wt} \% \mathrm{KOH}$ are shown in Figures $7 \mathrm{a}$ and $7 \mathrm{~b}$, respectively. The FTIR and ${ }^{1} \mathrm{H}$ NMR spectra of the membrane that had been operated in $5 \mathrm{wt} \% \mathrm{KOH}$ were practically identical with those of the starting material. The FTIR spectrum of the membrane that had been operated in $15 \mathrm{wt} \%$ showed a broadening of the strong absorption band around $1400 \mathrm{~cm}^{-1}$, which was developed into a distinct peak at $1380 \mathrm{~cm}^{-1}$ in the spectrum of the membrane operated in $30 \mathrm{wt} \% \mathrm{KOH}$. This band has previously been assigned to free amino groups originating from base catalyzed hydrolysis of the polymer backbone. ${ }^{4}$ This degradation mechanism is further supported by the development of an absorption band at 1690 $\mathrm{cm}^{-1}$, indicating formation of carbonyl moieties. ${ }^{56,57}$ Furthermore, weak signals at 5.33, 6.66 and $7.20 \mathrm{ppm}$ appeared in the ${ }^{1} \mathrm{H}$ NMR spectra of $m$-PBI after operation in 15 and $30 \mathrm{wt} \% \mathrm{KOH}$, likely originating from amino-groups. For comparison, the amino groups of the tetramine monomer (3,3'-diaminobenzidine) used for the synthesis of $m$-PBI are found at around $6.14 \mathrm{ppm}$. Furthermore, a weak signal at $8.8 \mathrm{ppm}$ could be observed in the spectra, as previously observed in the ${ }^{1} \mathrm{H}$ NMR spectrum of $m$-PBI after aging in aqueous $\mathrm{KOH}$ in the higher concentration range for 6 months at close to $90^{\circ} \mathrm{C}{ }^{44,47}$ Quantitative information could, however, not be obtained due to incomplete dissolution in the NMR solvent.

The thermogravimetric curves of the reference material and of the $m$-PBI membranes after operation at $2.0 \mathrm{~V}$ for $48 \mathrm{~h}$ in 5,15 and $30 \mathrm{wt} \%$ $\mathrm{KOH}$ are shown in Figure 8. As previously discussed, ${ }^{47}$ the thermooxidative degradation of $m$-PBI occurs in two steps with major onsets at 554 and $660^{\circ} \mathrm{C}$. The thermogravimetric curve of the membrane after operation at $2.0 \mathrm{~V}$ for $48 \mathrm{~h}$ in $5 \% \mathrm{KOH}$ was practically identical with that of the reference material, indicating limited structural changes of the polymer. For the membrane operated in $15 \% \mathrm{KOH}$ under similar conditions, the onset temperature of the second decomposition step was lowered to $637^{\circ} \mathrm{C}$. After operation in $30 \%$ the second onset appeared as a diffuse shoulder at around $600^{\circ} \mathrm{C}$. A similar shift of the second onset of decomposition to lower temperatures has previously been observed for $m$-PBI membranes after aging in $25-50 \mathrm{wt} \%$ aqueous $\mathrm{KOH}$ for about 6 months. ${ }^{47}$

The size exclusion chromatograms of $m$-PBI after water electrolysis operation in 5,15 and $30 \mathrm{wt} \% \mathrm{KOH}$ for 2 days at 1.7 or $2.0 \mathrm{~V}$ are shown in Figure 9. In general, a peak broadening toward higher retention times can be observed with increasing $\mathrm{KOH}$ concentration. Furthermore, the effect seems more pronounced after operation at higher cell voltage and therefore higher current densities. This clearly indicates increasing fraction of low molecular weight $m$-PBI, as previously observed for $m$-PBI membranes kept in aqueous $\mathrm{KOH}$ of high concentrations at close to $90^{\circ} \mathrm{C}$ for 6 months. ${ }^{47}$ It should be remarked that a minor fraction of the samples that had been operated in 15 and $30 \mathrm{wt} \%$ was insoluble in DMAc after electrolysis testing. The gel content was estimated to about $5 \%$.

The molecular weight data were obtained from calibrations with poly(methyl methacrylate) standards and summarized in Table I. The peak molecular weights $M_{p}$ shifted from $195000 \mathrm{~g} \mathrm{~mol}^{-1}$ for the reference material to 191000,185000 and $159000 \mathrm{~g} \mathrm{~mol}^{-1}$ after operating at $2.0 \mathrm{~V}$ in 5,15 and $30 \mathrm{wt} \%$ aqueous $\mathrm{KOH}$, respectively. At the

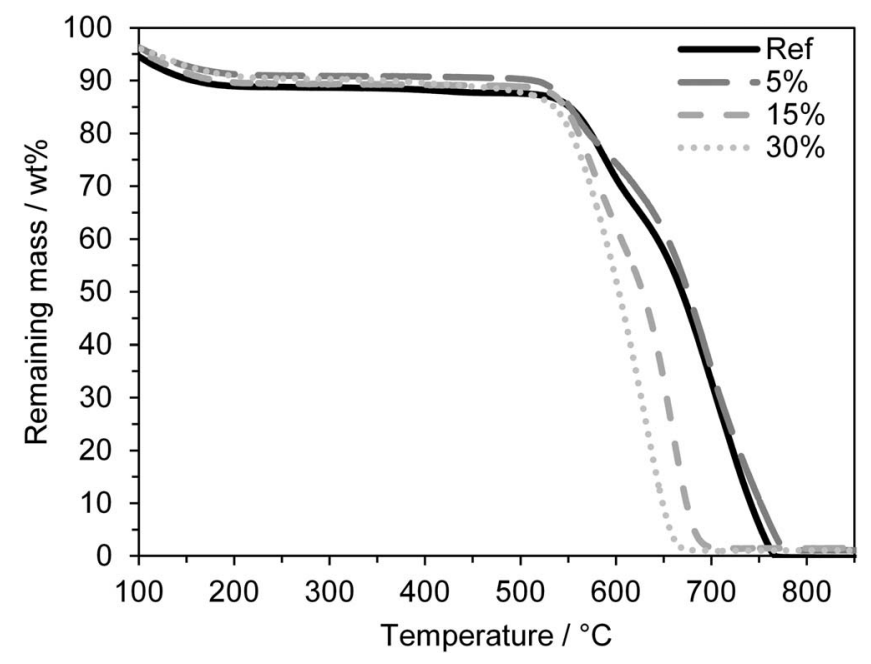

Figure 8. Thermogravimetric curves of $m$-PBI after water electrolysis operation for $48 \mathrm{~h}$ at $2.0 \mathrm{~V}$ in 5,15 and $30 \mathrm{wt} \%$ aqueous $\mathrm{KOH}$. 

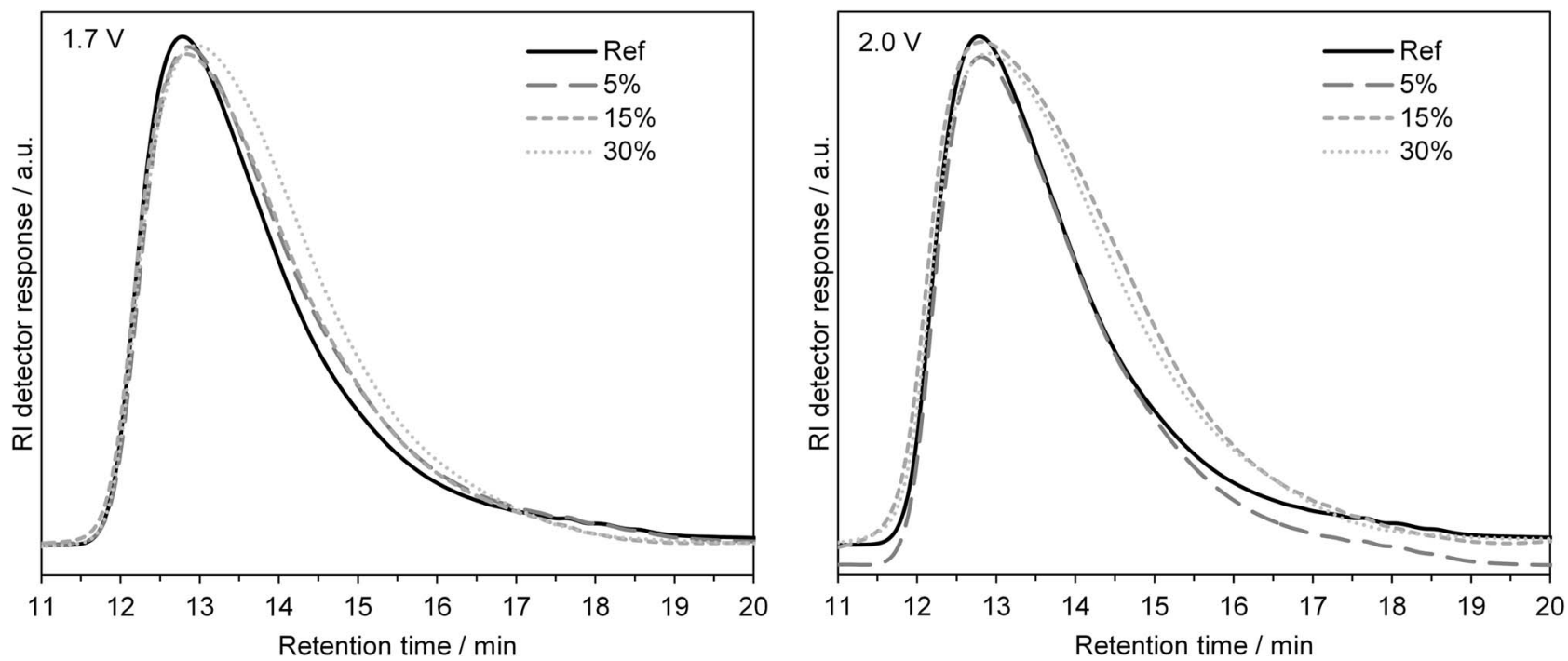

Figure 9. Size exclusion chromatograms of $m$-PBI after water electrolysis operation for $48 \mathrm{~h}$ at $1.7 \mathrm{~V}$ (left) and $2.0 \mathrm{~V}$ (right) in 5,15 and $30 \mathrm{wt} \%$ aqueous KOH.

Table I. Summary of molecular weight data calculated on basis of calibration with a poly(methyl methacrylate) standard.

\begin{tabular}{|c|c|c|c|c|c|c|}
\hline & \multicolumn{2}{|c|}{$M_{p} \times 10^{-3} / \mathrm{g} \mathrm{mol}^{-1}$} & \multicolumn{2}{|c|}{$M_{n} \times 10^{-3} / \mathrm{g} \mathrm{mol}^{-1}$} & \multicolumn{2}{|c|}{ PDI } \\
\hline & $1.7 \mathrm{~V}$ & $2.0 \mathrm{~V}$ & $1.7 \mathrm{~V}$ & $2.0 \mathrm{~V}$ & $1.7 \mathrm{~V}$ & $2.0 \mathrm{~V}$ \\
\hline Ref & \multicolumn{2}{|c|}{195} & \multicolumn{2}{|c|}{66} & \multicolumn{2}{|c|}{2.61} \\
\hline $5 \%$ & 180 & 191 & 57 & 59 & 2.81 & 2.95 \\
\hline $15 \%$ & 178 & 185 & 68 & 61 & 3.15 & 6.86 \\
\hline $30 \%$ & 150 & 159 & 50 & 60 & 3.19 & 7.37 \\
\hline
\end{tabular}

same time the polydispersity index was increased from 2.61 for the reference material to $2.95,6.86$ and 7.37 , indicating a broadening of the molecular weight distribution. This effect was further strengthened by the increasing weight average molecular weight $M_{w}$, likely due to agglomeration or partial oxidative crosslinking of the polymer as also supported by the existence of a small insoluble fraction. This phenomenon is different from the effect observed under simulated conditions in aqueous $\mathrm{KOH}^{47}$ or in the Fenton solution, ${ }^{56}$ indicating a different degradation mode during in situ operation.

In brief, operation at $2.0 \mathrm{~V}$ in $5 \mathrm{wt} \% \mathrm{KOH}$ resulted in very limited degradation of the polymer. Higher rates of the electrochemical reactions were obtained at the same cell voltage when the KOH concentration was increased to 15 and $30 \mathrm{wt} \%$, which resulted in enhanced membrane degradation. Generally, the rate of hydrolysis of $m$-PBI in aqueous $\mathrm{KOH}$ increases with increasing $\mathrm{KOH}$ concentration ${ }^{47}$ but whether the effect observed here is due to the increased $\mathrm{KOH}$ concentration or due to the higher rates of the electrochemical processes remain to be investigated. It is, however, anticipated that further exploration of the degradation modes under cell operation will provide information for the rational design of new polybenzimidazole derivatives with improved long-term stability.

\section{Conclusions}

Membranes based on $m$-PBI can be used as electrolytes in an alkaline water electrolyzer with zero-gap design, showing considerable better performance than traditional porous separators even at lower concentrations of the aqueous $\mathrm{KOH}$ electrolyte. The best performance was achieved in $20-25 \mathrm{wt} \%$ aqueous $\mathrm{KOH}$, which is also the concentration range where the ion conductivity reached a maximum at $20-80^{\circ}$ C. Stable water electrolysis operation was demonstrated for 2 days in 5, 15 and $30 \mathrm{wt} \% \mathrm{KOH}$. Post analysis of the membrane revealed evidence of oxidative degradation of $m$-PBI after operation in 15 and $30 \mathrm{wt} \% \mathrm{KOH}$, likely with a different degradation mode than observed ex-situ. In $5 \mathrm{wt} \% \mathrm{KOH}$ the membrane degradation was very limited even after 2 days at $2.0 \mathrm{~V}$. Higher $\mathrm{KOH}$ concentration and/or higher cell voltage resulted in enhanced degradation. As a result, the membrane stability on one hand must be balanced against cell performance on the other. Further exploration of the degradation modes under cell operation will provide information for the rational design of new polybenzimidazole derivatives with improved long-term stability for advanced alkaline water electrolyzers.

\section{Acknowledgments}

This work was financially supported by DTU Energy. Danish Power Systems ApS is gratefully acknowledged for supplying the $m$-PBI used in this work.

\section{References}

1. M. Götz, J. Lefebvre, F. Mörs, A. McDaniel Koch, F. Graf, S. Bajohr, R. Reimert, and T. Kolb, Renew. Energy, 85, 1371 (2016).

2. K. Zeng and D. Zhang, Prog. Energy Combust. Sci., 36, 307 (2010).

3. A. Ursúa, L. M. Gandía, and P. Sanchis, Proc. IEEE, 100, 410 (2012).

4. X. H. Li, F. C. Walsh, and D. Pletcher, Phys. Chem. Chem. Phys., 13, 1162 (2011)

5. X. Lu and C. Zhao, Nat. Commun., 6, 6616 (2015).

6. B. Zhang, X. Zheng, O. Voznyy, R. Comin, M. Bajdich, M. García-Melchor, L. Han, J. Xu, M. Liu, L. Zheng, F. P. García de Arquer, C. T. Dinh, F. Fan, M. Yuan, E. Yassitepe, N. Chen, T. Regier, P. Liu, Y. Li, P. De Luna, A. Janmohamed, H. L. Xin, H. Yang, A. Vojvodic, and E. H. Sargent, Science, 352, 333 (2016).

7. D. Pletcher, X. Li, and S. Wang, Int. J. Hydrogen Energy, 37, 7429 (2012).

8. C. K. Kjartansdóttir, L. P. Nielsen, and P. Møller, Int. J. Hydrogen Energy, 38, 8221 (2013).

9. Y. Zhu, X. Zhang, J. Song, W. Wang, F. Yue, and Q. Ma, Appl. Catal. A Gen., 500, $51(2015)$.

10. M. Carmo, D. L. Fritz, J. Mergel, and D. Stolten, Int. J. Hydrogen Energy, 38, 4901 (2013).

11. R. J. Guanti and P. J. Moran, J. Appl. Electrochem., 16, 678 (1986).

12. D. M. See and R. E. White, J. Chem. Eng. Data, 42, 1266 (1997).

13. R. J. Gilliam, J. W. Graydon, D. W. Kirk, and S. J. Thorpe, Int. J. Hydrogen Energy, 32, 359 (2007). 
14. F. Allebrod, C. Chatzichristodoulou, and M. B. Mogensen, J. Power Sources, 229, 22 (2013).

15. J. Kerres, G. Eigenberger, S. Reichle, V. Schramm, K. Hetzel, W. Schnurnberger, and I. Seybold, Desalination, 104, 47 (1996).

16. J. Otero, J. Sese, I. Michaus, M. Santa Maria, E. Guelbenzu, S. Irusta, I. Carrilero, and M. Arruebo, J. Power Sources, 247, 967 (2014).

17. D. Burnat, M. Schlupp, A. Wichser, B. Lothenbach, M. Gorbar, A. Zuttel, and U. F. Vogt, J. Power Sources, 291, 163 (2015).

18. K. Vazač, M. Paidar, M. Roubalik, and K. Bouzek, Chem. Eng. Trans., 41, 187 (2014).

19. D. Aili, M. K. Hansen, J. W. Andreasen, J. Zhang, J. O. Jensen, N. J. Bjerrum, and Q. Li, J. Membr. Sci., 493, 589 (2015).

20. H. Cheng, K. Scott, and C. Ramshaw J. Electrochem. Soc., 149, D172 (2002).

21. T. Iida, H. Matsushima, and Y. Fukunaka, J. Electrochem. Soc., 154, E112 (2007)

22. S. Marini, P. Salvi, P. Nelli, R. Pesenti, M. Villa, M. Berrettoni, G. Zangari, and Y. Kiros, Electrochim. Acta, 82, 384 (2012).

23. D. Pletcher and X. Li, Int. J. Hydrogen Energy, 36, 15089 (2011).

24. Y.-C. Cao, X. Wu, and K. Scott, Int. J. Hydrogen Energy, 37, 9524 (2012).

25. Y. J. Leng, G. Chen, A. J. Mendoza, T. B. Tighe, M. A. Hickner, and C. Y. Wang, J. Am. Chem. Soc., 134, 9054 (2012).

26. L. Xiao, S. Zhang, J. Pan, C. Yang, M. He, L. Zhuang, and J. Lu, Energy Environ. Sci., 5, 7869 (2012).

27. C. G. Arges and V. Ramani, Proc. Natl. Acad. Sci. U. S. A., 110, 2490 (2013).

28. M. G. Marino and K. D. Kreuer, ChemSusChem, 8, 513 (2015).

29. G. Merle, M. Wessling, and K. Nijmeijer, J. Membr. Sci., 377, 1 (2011).

30. B. Xing and O. Savadogo, Electrochem. Commun., 2, 697 (2000).

31. D. Aili, K. Jankova, J. Han, N. J. Bjerrum, J. O. Jensen, and Q. Li, Polymer, 84, 304 (2016).

32. L. Zeng, T. S. Zhao, L. An, G. Zhao, and X. H. Yan, J. Membr. Sci., 493, 340 (2015).

33. H. Zarrin, G. Jiang, G. Y. Y. Lam, M. Fowler, and Z. Chen, Int. J. Hydrogen Energy, 39, 18405 (2014).

34. L. Zeng, T. S. Zhao, L. An, G. Zhao, and X. H. Yan, Energy Environ. Sci. 8, 2768 (2015).

35. H. Hou, G. Sun, R. He, B. Sun, W. Jin, H. Liu, and Q. Xin, Int. J. Hydrogen Energy, 33, 7172 (2008).

36. A. D. Modestov, M. R. Tarasevich, A. Y. Leykin, and V. Y. Filimonov, J. Power Sources, 188, 502 (2009).

37. A. Y. Leykin, O. A. Shkrebko, and M. R. Tarasevich, J. Membr. Sci., 328, 86 (2009).

38. H. Hou, S. Wang, Q. Jiang, W. Jin, L. Jiang, and G. Sun, J. Power Sources, 196, 3244 (2011).
39. R. N. Couto and J. J. Linares, J. Membr. Sci, 486, 239 (2015).

40. C. Xu, J. Yan, Q. Qin, Y. Deng, J. Cheng, Y. Zhang, and Y. Wu, RSC Adv., 6, 19826 (2016).

41. K. Matsumoto, T. Fujigaya, H. Yanagi, and N. Nakashima, Adv. Funct. Mater, 21, 1089 (2011)

42. T. Fujigaya, C. Kim, K. Matsumoto, and N. Nakashima, ChemPlusChem, 79, 400 (2014).

43. H. Zarrin, J. Fu, G. Jiang, S. Yoo, J. Lenos, M. Fowler, and Z. Chen, ACS Nano, 9 , 2028 (2015)

44. D. Aili, M. K. Hansen, R. F. Renzaho, Q. Li, E. Christensen, J. O. Jensen, and N. J. Bjerrum, J. Membr. Sci., 447, 424 (2013).

45. J. O. Jensen, D. Aili, M. K. Hansen, Q. Li, N. J. Bjerrum, and E. Christensen, ECS Trans., 64, 1175 (2014).

46. L. A. Diaz, J. Hnát, N. Heredia, M. M. Bruno, F. A. Viva, M. Paidar, H. R. Corti, K. Bouzek, and G. C. Abuin, J. Power Sources, 312, 128 (2016).

47. D. Aili, K. Jankova, Q. Li, N. J. Bjerrum, and J. O. Jensen, J. Membr. Sci., 492, 422 (2015).

48. Section 5: Concentrative properties of aqueous solutions: Density, refractive index, freezing point depression, and viscosity, in: CRC Handbook of Chemistry and Physics, 93rd Edition, W. M. Haynes (Ed.), CRC Press/Taylor and Francis, Boca Raton, Internet Version, 2013.

49. M. Tuckerman, K. Laasonen, M. Sprik, and M. Parrinello, J. Chem. Phys., 103, 150 (1995).

50. M. E. Tuckerman, D. Marx, and M. Parrinello, Nature, 417, 925 (2002)

51. M. G. Marino, J. P. Melchior, A. Wohlfarth, and K. D. Kreuer, J. Membr. Sci., 464, $61(2014)$

52. L. Trotochaud, S. L. Young, J. K. Ranney, and S. W. Boettcher, J. Am. Chem. Soc., 136, 6744 (2014).

53. S. Klaus, Y. Cai, M. W. Louie, L. Trotochaud, and A. T. Bell, J. Phys. Chem. C, 119 7243 (2015).

54. D. Aili, J. Zhang, M. T. Dalsgaard Jakobsen, H. Zhu, T. Yang, J. Liu, M. Forsyth, C. Pan, J. O. Jensen, L. N. Cleemann, S. P. Jiang, and Q. Li, J. Mater. Chem. A, 4, 4019 (2016)

55. D. Aili, M. K. Hansen, C. Pan, Q. Li, E. Christensen, J. O. Jensen, and N. J. Bjerrum, Int. J. Hydrogen Energy, 36, 6985 (2011).

56. J. H. Liao, Q. F. Li, H. C. Rudbeck, J. O. Jensen, A. Chromik, N. J. Bjerrum, J. Kerres, and W. Xing, Fuel Cells, 11, 745 (2011).

57. D. Aili, L. N. Cleemann, Q. Li, J. O. Jensen, E. Christensen, and N. J. Bjerrum, J. Mater. Chem., 22, 5444 (2012). 